\title{
The Influence of Intellectual Capital, Innovation and Knowledge Management on Firm Performance
}

\author{
Anthonius S. Hutabarat ${ }^{1}$, Hadita ${ }^{2}$ \\ 1 Universitas Bina Nusantara Jakarta, Indonesia \\ ${ }^{2}$ Universitas Bhayangkara Jakarta Raya, Indonesia \\ Email: ahutab@gmail.com
}

\begin{abstract}
This study aims to determine the effect of Intellectual Capital, Innovation, and Knowledge Management on firm performance. This research uses quantitative research with a descriptive analysis approach. The data used are primary and secondary. The population in this study are all MSME companies engaged in the fashion sector. At the same time, the samples in this study were 10 MSME Fashion companies in Jakarta, which were selected by random sampling method. The data collection method used in this research is field research in observation, interviews and questionnaires, and library research. The data analysis method used to determine the independent variable on the dependent variable used multiple linear regression formula using SPSS Version 20.0. A data analysis method is a tool used in solving problems. In addition, the analysis of research data using Validity Test, Reliability Test, Multiple Linear Regression Test and Hypothesis Testing. Based on the results of data analysis, it can be concluded that: 1) Intellectual Capital and Knowledge Management have a positive and significant effect on the performance of MSME Fashion companies in Jakarta, and 2) Innovation does not have a positive effect on the performance of MSME Fashion companies in Jakarta.
\end{abstract}

Keywords: Influence, Intellectual Capital, Innovation, Knowledge Management, Firm Performance, Fashion.

\section{A. INTRODUCTION}

The world is entering the era of the global economy; companies are led to competing in the new international economic arena and the generation of disruption, the resources used to lead to knowledge-based resources as the main factor to maintain competitiveness and firm performance (Efendi, 2020). This is supported by Arifin (2016) research results using the Generalized Structural Component Analysis (GSCA) analysis method. According to this research, intellectual property has a favorable and considerable effect on a firm's financial performance.

In the era of globalization, economic development is increasing. Business people constantly innovate their business. Tight competition and increasingly high market need force business people to increase their capacity (Sumardi \& Efendi, 2021). Companies that rely on tangible assets are not enough to compete; business people are starting to realize that success in doing business depends on tangible assets, but intangible assets also have an essential role in supporting business success. Business people are beginning to realize the importance of this (Efendi, 2021). In Indonesia, intellectual capital is still mostly unknown. Until date, Indonesian businesses have tended to develop their businesses on traditional 
principles, leaving their products deficient in technological content. Additionally, these businesses have not placed a higher premium on human capital, structural capital, or customer capital. All of these activities contribute to the development of the firm's intellectual capital. This conclusion can be drawn because of Indonesia's lack of information about intellectual capital (Efendi \& Winenriandhika, 2021).

Foreign companies entering the Indonesian market require native firms to further enhance their value and performance in order to compete against increasingly tough competition (Sugiono et al., 2020). Businesses require more relevant information about the aspects measured not only by tangible assets but also by intangible assets in order to determine the firm's value and performance during the improvement process. While recognition of Intellectual Capital's role in generating firm value and competitive advantage has grown, an acceptable measure of Intellectual Capital (IC) is still being established. In addition, in the era of globalization where competition in all business sectors is getting sharper, companies are expected to choose the right strategy to compete with their opponents in the market. In this case, the firm's innovation factor also has its central point in determining its performance (Alwi \& Sugiono, 2020). In this high-speed digital era, firm changes and innovations are not only things that are done occasionally, but this becomes mandatory if companies are still willing to compete in the global arena. Competition conditions are increasingly competitive, dynamic and require an aggressive, innovative attitude. The increasingly fierce competition also impacts the need for companies to be more flexible, adaptive and act quickly. Innovation affects the firm's performance (Efendi \& Winenriandhika, 2021).

Innovation is defined as the successful implementation of novel ideas within a business. Innovation is a strategy used by businesses to adapt to a changing environment (Sugiono, 2021). As a result, businesses must be able to generate assessments and new ideas, as well as offer creative products. The purpose of product innovation is to satisfy market demand so that the firm can leverage product innovation as a competitive advantage. It is considered that innovative products boost a corporate organization's sales, earnings, and competitiveness. Nonetheless, producing innovative items entails the danger that they will become costly and risky for the business (Alwi, 2021). Therefore, proper and accurate coordination is needed between the divisions in the firm to make the right product for the market.

Today's competition for micro, small, and medium-sized businesses (MSMEs) is becoming more intense. According to data obtained from the Indonesian Ministry of Cooperatives and SMEs (www.ukmindonesia.id), MSME units will account for approximately 99.99 percent (62.9 million units) of all business actors in Indonesia in 2020, while large businesses will account for approximately 0.01 percent (5400 units). Micro-enterprises employ around 107.2 million people (89.2 percent), small businesses employ approximately 5.7 million people (4.74 percent), and mediumsized businesses employ approximately 3.73 million people (3.11 percent), while large firms employ approximately 3.58 million people. Thus, MSMEs account for 
around 97 percent of the whole national labor, whereas large firms account for approximately $3 \%$ of the overall federal workforce.

Micro, small and medium enterprises engaged in fashion currently have a role in the economy. Various digital platforms market fashion products and are a comprehensive market for business people and companies. The success of a business can be seen through the performance of the business. Version refers to the level of achievement or achievement of the firm in a certain period. Entrepreneurial skills are identified as one of the factors that affect business performance. Entrepreneurial skills are the activities or knowledge to build and operate a business successfully creatively.

In this digital era, knowledge management is very central in business. Research conducted by Apriani et al. (2020) shows that knowledge management is central to the development of companies in the digital era with the power of innovation and the power of networks. A network is a bond that connects business actors various businesses, such as business partners, friends, agents or mentors, to get the resources needed, such as information, money and moral support of network actors that will affect the firm's performance.

The dynamics of the external environment in which the firm as an open system operates continues to increase in volatility. Companies accustomed to formulating their business strategies by predicting trends in the next five to ten years are frustrated because changes occur very quickly and cannot be expected. Product life cycles are getting shorter, consumer tastes constantly change as lifestyles change, and resources are scarcer. Competition is also getting more challenging, coupled with the emergence of new competitors who come from different industries with different strategies. Thin margins reduce the firm's flexibility and ability to continue to grow. At this time, companies are competing to find new sources of competitive advantage, which are rare, difficult to imitate and can be used continuously.

These various breakthroughs are considered substantial factors to support the competitive value of MSME Fashion in Jakarta and can be a good potential and even become superior for gaining foreign exchange. Creative economy actors create a lot of diversity of ideas, materials, designs to the characteristics of fashion works and accessories, resulting from the empowerment of intellectual capital combined with innovations that attract customers' interest. For example, many companies engaged in the fashion sector create shoes, sneakers, fashion made from used clothing, handmade socks, jackets, bags, and eco-fashion.

In 2019, the fashion and textile industry contributed about 18 per cent of state revenue but had continued to decline since the beginning of 2020. This is due to declining purchasing power and people's needs. During a pandemic like now, various online fashion shopping festivals have become the firm's financial support. Of the total 13.7 million MSMEs that have made online sales, $40.5 \%$ are still concentrated in Jakarta, then in second place in West Java (21\%), East Java (7\%), and Central Java $(6.5 \%)$. 
In the Resource-Based View of the firm (RBV) theory, it is stated that a resource is said to be strategic if it meets several criteria, namely rare, valuable, difficult to imitate and challenge to replace. Furthermore, although the knowledgebased view of the firm (KBV) theory still cannot be called a theory, for its supporters, knowledge is seen as the most strategic resource because it meets the criteria presented above. Moreover, the concept of business learning emphasizes that knowledge is the result of learning. A superior firm is a firm that can learn, generate knowledge so that it does not repeat past mistakes and can produce breakthroughs. The great potential of MSME Fashion must, of course, be supported by the firm's internal power and potential such as IC, innovation and knowledge management as a strategy to improve quality, competitiveness, and firm performance.

\section{B. LITERATURE REVIEW}

\section{Intellectual Capital}

Intellectual capital can be defined as knowledge used to develop intellectual property and experience that can be used to generate riches as a driver of business value and a competitive advantage in the future. The efficiency of the added value provided by the firm's intellectual talent is recommended as a proxy for intellectual capital (Value Added Intellectual Coefficient - VAIC).

The performance of intellectual capital is determined by the value added generated by physical capital (VACA), human capital (VAHU), and structural capital (STVA). The combination of the three value-added is denoted by the term VAIC, which was coined by the public. The VAIC formula is as follows: a) Output (OUT) equals total sales and other income; b) Input (IN) equals expenses and costs (other than employee expenses); c) Value Added (VA) equals the difference between Output and Input; d) Human Capital (HC) equals employee expenses; e) Capital Employed (CE) equals available funds (equity, net income); and f) Structural Capital (SC) equals VA Companies that reveal intellectual capital have a higher perceived worth in the eyes of investors, as investors are often more interested in companies that provide comprehensive information about their operations in order to boost the firm's value. Intellectual capital is critical and plays a critical strategic function in the firm. Intellectual capital refers to the knowledge and talents of a social collectivity, such as an organization, an intelligent community, or a profession.

Mubarik et al. (2021) classify intellectual capital into three categories: (1) human capital, (2) structural capital, and (3) customer capital. According to research findings, intellectual capital has a favorable and significant effect on a business's performance. Intellectual capital is intellectual property that has been institutionalized, captured, and used to create higher-value assets. Each organization accumulates intellectual property in the form of assets and resources, explicit and implicit viewpoints and capabilities, data, knowledge, and possibly policies.

The findings of this study are verified by Ali \& Anwar's (2021) research, which establishes intellectual capital as the essential unit and the most crucial capital in enhancing a business's worth in the digital era. Conservatism accounting practice 
stresses that the increase in the discrepancy between market and book value results from the firm's investment in intellectual capital. Thus, if the market is efficient, investors will place a premium on enterprises with superior intellectual capital. Additionally, if Intellectual Capital is a quantifiable resource for enhancing competitive advantages, it will contribute to the financial performance of the business. Then a hypothesis can be drawn as follows:

H1: Intellectual Capital has a positive and significant effect on the performance of MSME Fashion companies in Jakarta.

\section{Innovation}

Today for many industries, new product development is the most critical factor in controlling the success or failure of the firm. Companies must simultaneously find two crucial goals for successful new product development: maximizing precisely what consumers need and minimizing product entry time into the market (Schilling \& Hill, 1998).

Furthermore, Schilling and Hill state that the firm's success continues to be based on strategic goals and maps of its R\&D portfolio to precisely match the goals of new product development with the resources and competencies it currently has. Innovation is defined as the successful implementation of novel ideas within a business. Innovation is a strategy used by businesses to adapt to a changing environment. As a result, businesses must be able to generate assessments and new ideas, as well as offer creative products.

According to Hameed et al. (2021), innovation is a strategy used by businesses to adapt to changing conditions. As a result, businesses must generate fresh thoughts and ideas by producing innovative products and enhancing customer service. The two notions offered are inventiveness and inventive potential. Innovativeness is the concept of successfully embracing new ideas, procedures, and products.

According to Bouncken et al. (2020), the term innovation is directly tied to technology that enables a corporation to get insights into a new product or improve the design and manufacturing of existing products (services). The benefits of new products are inextricably linked to the process of new product creation. The new product development process is defined as the process of comprehending and developing a new product, as well as the products that arise from that process.

The characteristics of the advantages of new products in the competition can be found in several ways, namely: the features of the product in question, unique shapes and packaging, satisfactory after-sales service, pioneering product functions, various or multifunctional products and so on. Factors that influence the success of new products in four categories: 1) competitive conditions; 2) The firm's internal condition; 3) The process of developing new products, and 4) The competitive advantage of the product. Based on this description, new product innovation indicators can be raised: uniqueness, quality, and multi-functionality. Then a hypothesis can be drawn as follows: 
H2: Product innovation has a positive and significant impact on the performance of MSME Fashion companies in Jakarta.

\section{Knowledge Management}

Knowledge management can be defined as any process or practice that involves the creation, acquisition, capture, sharing, and use of knowledge with the purpose of enhancing learning and organizational performance. Knowledge management is the act of managing corporate knowledge with the purpose of generating business value and sustaining a competitive advantage through the optimization of the process of designing, communicating, and applying all necessary knowledge to accomplish firm goals. The American Productivity and Quality Center (APQC) defines knowledge management as "systems techniques that facilitate the emergence and flow of information and knowledge to the appropriate people at the appropriate time in order to generate value." Meanwhile, Nisa (2016) describes knowledge management as the process of obtaining and employing a collection of firm expertise located in a business, paper, document, database, or in one's mind (explicit knowledge) (tacit knowledge).

According to these experts, knowledge management is a collection of methods for developing, disseminating, and using corporate information in order to generate commercial value and improve employee and organizational learning and performance. There are two fundamental approaches to knowledge, namely tacit knowledge, which is personal, so it is difficult to extract from the individual's head (intimate knowledge) and explicit knowledge which assumes that knowledge that is beneficial to individuals in the organization can be articulated made clear. Detailed knowledge in this research is job procedure and technology.

This statement is supported by the results of research conducted by Abdul Latief et al. (2019), knowledge and skills management has a positive and significant effect on firm performance. Knowledge management is one of the essential factors in the 21st century to achieve effective managerial career management in identifying and transferring knowledge of Human Resources in carrying out firm activities by completing them on time and having creative and innovative employees to bring the firm to superior performance. The balance between technology and competent Human Resources to run it, so you can imagine if a firm with sophisticated equipment and technology, but the competence of Human Resources is inadequate and unable, it can undoubtedly have fatal consequences. In contrast to the role of Human Resources in the past, which was less active and seemed passive, the role of Human Resources today must be proactive. It must have the firm's trust so that the feelings and behaviour of good Human Resources will make work attitudes in the firm more comfortable. Run business processes following Standard Operating Procedures (SOP). Then a hypothesis can be drawn as follows:

H3: Knowledge Management has a positive and significant effect on the performance of MSME Fashion companies in Jakarta. 


\section{METHOD}

This research uses quantitative research with a descriptive analysis approach. The data used are primary and secondary. The population in this study are all MSME companies engaged in the fashion sector. At the same time, the samples in this study were 10 MSME Fashion companies in Jakarta, which were selected by random sampling method. The data collection method used in this research is field research in observation, interviews and questionnaires, and library research. Data analysis methods used to determine the independent variable on the dependent variable used multiple linear regression formula using SPSS Version 20.0. A data analysis method is a tool used in solving problems. In addition, the research data analysis used the methods of Validity Test, Reliability Test, Multiple Linear Regression Test and Hypothesis Testing.

\section{RESULT AND DISCUSSION}

\section{Description of Research Respondents}

This research was conducted on 10 MSME Fashion in Jakarta. The quantitative data type was obtained from distributing questionnaires to $10 \mathrm{MSME}$ Fashion companies in Jakarta. Respondent data is presented in the following table:

Table 1. Research Respondent Data

\begin{tabular}{|c|c|c|c|}
\hline No & Firm Code & Fashion field & Marketing Method \\
\hline 1. & AF & Jacket & Online and Offline \\
\hline 2. & DMF & Children clothes & Offline \\
\hline 3. & GIF & Socks and T-shirts & Online \\
\hline 4. & OPF & Sweaters & Online \\
\hline 5. & RF & Sock & Online \\
\hline 6 & RTF & Bag & Online \\
\hline 7. & UTF & Shoe & Online and Offline \\
\hline 8. & WSF & Dress & Online \\
\hline 9. & ASF & Trousers & Online and Offline \\
\hline 10. & CF & Accessories &
\end{tabular}

Source: Data Processed

Based on the data in table 1, companies still market their products offline, which is undoubtedly an ineffective strategy. Business actors do not fully understand the market potential of maximizing online sales on various digital platforms. It must be admitted that the Covid-19 pandemic has reduced people's purchasing power because the public has diminished outdoor interactions to suppress the spread of the pandemic. As a result, many consumers are now keeping their distance and switching purchases digitally. As a result, many MSMEs have to close their businesses due to declining investments and are still dependent on offline sales. So that several MSME sectors that have not adapted digitally are ultimately very affected and closed their outlets. Even so, the Covid-19 pandemic has indirectly prompted new changes in Indonesia's business style. The difference is the shift from 
offline business to digital business, also known as the phenomenon of digital entrepreneurship. Social media and marketplaces can be a concept to make it easier for MSME actors to get more comprehensive marketing access.

Therefore, an entrepreneurial model is needed that can adapt to technological advances. This is what gave birth to the digital entrepreneurship model. This business model is the result of a marriage of digital technology with entrepreneurship, resulting in a new type of business phenomena. In this instance, the role of digital technology has a major impact on the newly developed business divisions. Emerging technological paradigms enable entrepreneurs to build and launch more robust and durable entrepreneurial ventures by using the potential for cooperation and collective intelligence. Nonetheless, digital entrepreneurship has four dimensions: digital actors (who), digital actions (what), digital motivation (why), and digital organizations (how).

\section{Validity Test}

A validity test is used to correlate the scores of the answers to each question item posed to respondents with the number of variable scores. The correlation technique used is Pearson's product-moment. The number 0.281 ( $\mathrm{t}$-table) becomes a comparison to see whether or not an item in the study is valid. The results of validity testing in this study are presented in the following table:

Table 2. Validity Test Results

\begin{tabular}{|c|c|c|c|}
\hline Variable & Item & r count & Description \\
\hline \multirow{6}{*}{ Intellectual Capital } & 1 & .643 & Valid \\
\hline & 2 & .956 & Valid \\
\hline & 3 & .758 & Valid \\
\hline & 4 & .692 & Valid \\
\hline & 5 & .959 & Valid \\
\hline & 6 & .837 & Valid \\
\hline \multirow{6}{*}{ Innovation } & 1 & .771 & Valid \\
\hline & 2 & .768 & Valid \\
\hline & 3 & .554 & Valid \\
\hline & 4 & .838 & Valid \\
\hline & 5 & .773 & Valid \\
\hline & 6 & .756 & Valid \\
\hline \multirow{5}{*}{ Knowledge Management } & 1 & .930 & Valid \\
\hline & 2 & .865 & Valid \\
\hline & 3 & .883 & Valid \\
\hline & 4 & .737 & Valid \\
\hline & 5 & .958 & Valid \\
\hline \multirow{3}{*}{ Firm Performance } & 1 & .870 & Valid \\
\hline & 2 & .685 & Valid \\
\hline & 3 & .789 & Valid \\
\hline
\end{tabular}




\begin{tabular}{|c|c|c|c|}
\hline \multirow{2}{*}{} & 4 & .564 & Valid \\
\cline { 2 - 4 } & 5 & .669 & Valid \\
\cline { 2 - 4 } & 6 & .592 & Valid \\
\hline
\end{tabular}

Source: Data Processed

The validity of a question in research can be seen from various aspects, such as 1) Content validity, 2) Construct validity, and 3) Criteria Validity. In this study, the focus of each question item in this study is content validity. Content validity or content validity focuses on providing evidence on the elements in the measuring instrument and is processed by rational analysis. Experts assess content validity. When measuring instruments are described in detail, the assessment will be easier to do. The indicator that a device is valid is that the expert has received the agency, both in content and format, without any revision. If the expert still asks for improvement after the modification, the correction still needs to be done until the expert accepts the instrument without re-improvement. The correlation obtained from the questions on the indicators of each variable in this study is above the table number 0.281 , so the questions in this study are stated to be significant and have good validity.

\section{Reliability Test}

Reliability test is concerned with the extent to which a measurement can be trusted because of its consistency. An instrument with two or more answer choices is reliable if several times the height of the same subject (test-retest) results are obtained that are relatively the same, or in one measure with different instruments (equivalent), the results are relatively the same. The results of the reliability test in this study are presented in the following table:

Table 3. Reliability Test Results

\begin{tabular}{|c|c|c|c|}
\hline Variable & $\begin{array}{c}\text { Cronbach } \\
\text { Alpha Value }\end{array}$ & $\begin{array}{c}\text { Critical } \\
\text { Point }\end{array}$ & Description \\
\hline Intellectual Capital & .851 & 0.7 & Reliable \\
\hline Innovation & .869 & 0.7 & Reliable \\
\hline Knowledge Management & .773 & 0.7 & Reliable \\
\hline Firm performance & .817 & 0.7 & Reliable \\
\hline
\end{tabular}

Source: Data Processed

An instrument can be said to be reliable if $\mathrm{ri}>\mathrm{rt}$, while for the instrument in this study (with more than two answer choices), the item in the question can be said to be reliable if the Cronbach Alfa reliability is between 0.70-0.90. After calculating the Cronbach's Alpha reliability coefficient (ri), the value is compared to the Cronbach's Alpha reliability coefficient criterion for a dependable instrument. According to Nunnally (in Streiner, 2003), an instrument is considered dependable if the Cronbach's Alpha reliability coefficient exceeds 0.70 (ri > 0.70), whereas Streiner himself states that the Cronbach's Alpha reliability coefficient should not exceed 0.90 (ri 0.9). If the Cronbach's Alpha reliability coefficient is less than 0.70 (ri 0.70), 
Tavakol \& Dennick (2011) recommend changing or removing items with low correlations. A simple method for determining the object in question is to use a computer program. They also have ideas if the Cronbach's Alpha reliability coefficient is greater than 0.90 ( $\mathrm{ri}>0.90$ ). They proposed minimizing the amount of questions that shared the same inquiry criterion but were phrased differently. As a result, all things in this study can be considered credible.

\section{Multiple Linear Regression Test}

A regression test is used to determine the average estimated value and the value of the dependent variable, namely Firm Performance. Based on the independent variables, namely: 1) Intellectual Capital; 2) Innovation; and 3) Knowledge Management. In this study, the analysis used SPSS software. The results of the Multiple Linear Regression Test in this study are presented in the following table:

Table 4. Multiple Linear Regression Test Results

\begin{tabular}{|c|c|c|c|c|c|}
\hline \multirow{2}{*}{ Model } & \multicolumn{2}{|c|}{$\begin{array}{c}\text { Unstandardized } \\
\text { Coefficient }\end{array}$} & $\begin{array}{c}\text { Standardized } \\
\text { Coefficient }\end{array}$ & \multirow{2}{*}{$\mathbf{t}$} & Sig \\
\cline { 2 - 5 } & $\mathbf{B}$ & Std. Error & Beta & & .820 \\
\hline (Constant) & 3.836 & 4.794 & & .441 \\
\hline Intellectual Capital & .937 & .146 & .769 & 6.937 & .000 \\
\hline Innovation & -.317 & .173 & -.215 & 1.185 & .076 \\
\hline $\begin{array}{c}\text { Knowledge } \\
\text { Management }\end{array}$ & .821 & .136 & .737 & 6.826 & .067 \\
\hline
\end{tabular}

Source: Data Processed

Based on the data in table 4, the regression calculation in this study obtained the following equation: $\mathrm{Y}=3.836+0.937 \mathrm{X} 1-0.317 \mathrm{X} 2+0.821 \mathrm{X} 3$. This means that if all independent variables are 0 , then the value of the dependent variable is 3.836 . Variable $\mathrm{X}_{1}$ (Intellectual Capital) is 0.937 and is positive. This means that intellectual capital and firm performance are one-way. So the higher the intellectual capital owned by the firm, the better the firm's performance. Intellectual capital will increase if MSMEs conduct a lot of training for employees, such as regular training programs, rigorous employee recruitment, increasing individual potential, mentoring and maximizing all things that can increase the intellectual power of each firm employee.

The value of the $\mathrm{X}_{2}$ (Innovation) variable is 0.317 and is negative. This means that innovation and firm performance have an inverse relationship. MSME Fashion's innovations have had little impact on the firm's performance. The purpose of innovation or product innovation is to satisfy market demand and to position the firm's product as a competitive advantage. The innovations carried out by the firm do not touch the central point and the main problem of developing the value of fashion companies. This can be done by: 1) Product innovation that can ultimately control the market (market driving); 2) Companies that launch products must 
consider the risk of not being accepted by the market. 3) Companies must mobilize their human resources to explore new creations, and 4) The firm must educate the market.

Product leadership has the following characteristics: superior products, products that meet consumer needs, correct product prices, perfect technology, and product innovation. A superior product is a product that is superior and has differentiation above the products offered by competitors. The product also extends where the effect is felt to satisfy customer needs. The price of the product is also perceived by the customer following the value of the product.

While the variable $\mathrm{X}_{3}$ (Knowledge Management) is worth 0.821 , which is positive, the higher the knowledge management carried out by the firm, the better and higher the firm's performance. The sample companies in this study have carried out a series of systematic steps in managing knowledge assets, including 1) Collecting information about competing products in the fashion sector; 2) Save and create new designs in products, this is done by the design team in every MSME firm; 3) Disseminate knowledge through various platforms and social media, this is also done as a medium for promoting firm products.

\section{Partial Hypothesis Testing Intellectual Capital Variable}

The hypothesis in the Intellectual Capital variable is as follows:

Ha1: Intellectual Capital has a positive and significant effect on the performance of MSME Fashion companies in Jakarta.

Ha0: Intellectual Capital has no positive and significant effect on the performance of MSME Fashion companies in Jakarta.

Table 5. H1 Test Results

\begin{tabular}{|c|c|c|c|c|c|c|}
\hline & \multirow[t]{2}{*}{ Model } & \multicolumn{2}{|c|}{$\begin{array}{c}\text { Unstandardized } \\
\text { Coefficient }\end{array}$} & $\begin{array}{c}\text { Standardized } \\
\text { Coefficient }\end{array}$ & \multirow[t]{2}{*}{$\mathrm{t}$} & \multirow[t]{2}{*}{ Sig. } \\
\hline & & B & Std. Error & Beta & & \\
\hline 1 & (Constant) & 5.856 & 2.041 & \multirow{2}{*}{.736} & 2,766 & .006 \\
\hline \multicolumn{2}{|c|}{ Intellectual Capital $\left(\mathrm{X}_{1}\right)$} & .521 & .056 & & 11.225 & .004 \\
\hline
\end{tabular}

a. Dependent variable: Firm Performance

Source: Data processed

Based on the data in the table above, it can be seen that the X1 (Intellectual Capital) variable obtained a significance value of $t<0.05$ or $0.004<0.05$, and $t$ count $11.225>\mathrm{t}$ table 1.98. Then H1 is accepted. This shows that there is an influence between Intellectual Capital on firm performance. This strengthens the findings of research conducted by Christa (2018), which found that Intellectual Capital affects firm performance. Human Capital is the lifeblood in intellectual capital, meaning that human capital is the driving force in intellectual capital. There are characters, innovations, and ideas in good human resources that are very useful for companies that cannot be measured in monetary terms. This is the source of innovation and improvement, but it is a component that is difficult to measure because, so far, there 
has been no formal effort to measure these two components. Human capital is also a source of advantageous knowledge, skills, and competencies in an organization or firm.

Numerous scholars have empirically established a link between Intellectual Capital and financial performance of businesses using a variety of methodologies in a variety of countries. For example, according to study conducted in Canada by Mubarik et al. (2021), intellectual capital is a critical component of economic resilience in a variety of modern American businesses. Intellectual capital can be defined as knowledge used to develop intellectual property and experience that can be used to generate riches as a driver of business value and a competitive advantage in the future. The efficiency of the added value provided by the firm's intellectual capabilities is offered as an indirect indicator of Intellectual Capital.

\section{Innovation Variable}

The hypothesis in the Innovation variable is as follows:

Ha2: Innovation has a positive and significant impact on the performance of MSME Fashion companies in Jakarta.

Ha0: Intellectual innovation has no positive and significant effect on the performance of MSME Fashion companies in Jakarta.

Table 6. $\mathrm{H}_{2}$ Test Results

\begin{tabular}{|c|c|c|c|c|c|c|}
\hline \multirow{2}{*}{\multicolumn{2}{|c|}{ Model }} & \multicolumn{2}{|c|}{$\begin{array}{c}\text { Unstandardized } \\
\text { Coefficient }\end{array}$} & $\begin{array}{c}\text { Standardized } \\
\text { Coefficient }\end{array}$ & \multirow{2}{*}{$\mathrm{t}$} & \multirow{2}{*}{ Sig. } \\
\cline { 3 - 5 } \multicolumn{2}{c|}{} & $\mathrm{B}$ & Std. Error & Beta & & \\
\hline 1 & (Constant) & 5.856 & 2.041 & \multirow{2}{*}{.736} & 2.882 & .006 \\
\hline \multicolumn{2}{|c|}{ Innovation $\left(\mathrm{X}_{2}\right)$} & .536 & .072 & & 11.256 & .06 \\
\hline
\end{tabular}

a. Dependent variable: Firm performance

\section{Source: Data Processed}

Based on the data in the table above, it can be seen that the X2 (Innovation) variable obtained a significance value of $t>0.05$ or $0.06>0.05$, and $t$ count $11.256>t$ table 1.98. So Ha1 is rejected, and $\mathrm{HaO}$ is accepted. This shows that there is no influence between innovation on firm performance.

This is different from the results of research conducted by Kusumawati (2010), Hameed et al. (2021), and Bouncken et al. (2019), which found that innovation has a positive and significant effect on firm performance. Competition conditions are increasingly competitive, dynamic and require an aggressive, innovative attitude. The increasingly fierce competition also impacts the need for companies to be more flexible, adaptive and act quickly. Innovation is defined as the successful implementation of novel ideas within a business. Innovation enables businesses to adapt to a changing environment. As a result, businesses must be able to generate assessments and new ideas, as well as offer creative products. The purpose of product innovation is to satisfy market demand so that the firm can leverage product innovation as a competitive advantage. 
Product innovation is supposed to boost a corporate organization's sales, earnings, and competitiveness. Nonetheless, product innovation development can result in an expensive and risky product for the business. As a result, proper and exact coordination between the firm's divisions is required to provide the best product for the market. Innovation is a means of sustaining an organization's growth and development. It is accomplished through the introduction of new technologies, new applications in the form of products and services, the development of new markets, and the introduction of new organizational structures that combine various aspects of innovation to form the arena of innovation. Meanwhile, product innovations carried out by MSME Fashion companies have not satisfied market commodities. This is due to the immaturity of developing product variations in design, basic materials, marketing innovation and innovation to grow and expand market coverage.

\section{Knowledge Management Variables}

The hypothesis in the Innovation variable is as follows

Ha3: Knowledge Management has a positive and significant effect on the performance of MSME Fashion companies in Jakarta.

Ha0: Intellectual Knowledge Management has no positive and significant effect on the performance of MSME Fashion companies in Jakarta.

Table 7. H3 Test Result

\begin{tabular}{|c|c|c|c|c|c|c|}
\hline & \multirow[t]{2}{*}{ Model } & \multicolumn{2}{|c|}{$\begin{array}{c}\text { Unstandardized } \\
\text { Coefficient }\end{array}$} & $\begin{array}{c}\text { Standardized } \\
\text { Coefficient }\end{array}$ & \multirow[t]{2}{*}{$\mathrm{t}$} & \multirow[t]{2}{*}{ Sig. } \\
\hline & & B & Std. Error & Beta & & \\
\hline 1 & (Constant) & 5.856 & 2.041 & \multirow{2}{*}{.736} & 2.882 & .006 \\
\hline \multicolumn{2}{|c|}{ Knowledge Management $\left(X_{3}\right)$} & .547 & .076 & & 11.256 & .004 \\
\hline
\end{tabular}

a. Dependent variable: Firm performance

\section{Source: Data Processed}

Based on the data in the table above, it can be seen that the X3 (Knowledge Management) variable obtained a significance value of $t<0.05$ or $0.004<0.05$, and $t$ count $11.256>\mathrm{t}$ table 1.98. So Ha1 is accepted, and Ha0 is rejected. This shows that there is an influence between Knowledge Management on firm performance. These results are the following research conducted by Nisa et al. (2016), Latief et al. (2019), and Singh et al. (2014) that Knowledge Management has a positive and significant effect on firm performance.

The implementation of Knowledge Management in the sample companies was applied in several ways, including 1) Regular employee discussions; 2) Shirt Design Training; 3) Marketing training for the marketing team, and 4) Percentage of monthly evaluations. Knowledge Management $(\mathrm{KM})$ is measured by three indicators: knowledge acquisition, knowledge dissemination, response to knowledge. Three factors make up a knowledge management system: knowledge acquisition, knowledge dissemination, and response to the command. Knowledge acquisition does not directly affect the firm's performance. Information management 
can be defined as the process of transforming tacit knowledge into explicit knowledge that is then shared with organizational members.

The goal of knowledge management is to continuously enhance the operations of the business in order to achieve a competitive advantage and increase profits. Additionally, the knowledge management idea in a business tries to boost performance by developing a culture of knowledge sharing, in which knowledge is viewed as an asset that can be managed, conveyed, and used collaboratively. The firm's performance obtained at a time can be seen as a short-term achievement of the firm. The high and low level of short-term performance of the firm is an instrument for developing sustainable competitive advantage; the key to competitive advantage is that companies must constantly learn and continue to learn to improve Knowledge Management; this is very important because of the speed of knowledge about market potential, exciting fashion trends, as well as supply orientation is constantly changing and the characteristics of each time.

\section{E. CONCLUSION}

Based on the results of data analysis, it can be concluded that: 1) Intellectual Capital and Knowledge Management have a positive and significant effect on the performance of MSME Fashion companies in Jakarta, this is because the firm has implemented the implementation of employee selection and systematic improvement of knowledge of all employees; and 2) Innovation does not have a positive effect on the performance of MSME Fashion companies in Jakarta, this is due to the lack of knowledge about the market and current trends. The implementation of financial management has not been carried out in the application to the innovation of various fashion products marketed by the firm.

\section{REFERENCES}

1. Ali, B. J., \& Anwar, G. (2021). An Empirical Study of Employees' Motivation and its Influence Job Satisfaction. Ali, BJ, E Anwar, G. (2021). An Empirical Study of Employees' Motivation and its Influence Job Satisfaction. International Journal of Engineering, Business and Management, 5(2), 21-30.

2. Ali, B. J., \& Anwar, G. (2021). The Effect of Marketing Culture Aspects of Healthcare Care on Marketing Creativity. Ali, BJ, \& Anwar, G. (2021). The Effect of Marketing Culture Aspects of Healthcare Care on Marketing Creativity. International Journal of English Literature and Social Sciences, 6(2), 171-182.

3. Alwi, M., \& Sugiono, E. (2020). Pengaruh Rekrutmen, Penempatan Kerja dan Kompensasi Terhadap Kinerja Karyawan PT. Indoturbine Jakarta Pusat. Oikonomia: Jurnal Manajemen, 15(2).

4. Apriani, J. (2020). Faktor-Faktor Yang Memengaruhi Kinerja Usaha Mikro Kecil Dan Menengah Bidang Fashion. Faktor-Faktor Yang Memengaruhi Kinerja Usaha Mikro Kecil dan Menengah Bidang Fashion. 
5. Arifin, J. (2017). Corporate Governance and Intellectual Capital on Firm Value of Banking Sector Companies Listed at Indonesia Stock Exchange in 2008-2012. Wacana Journal of Social and Humanity Studies, 20(1).

6. Bouncken, R., Ratzmann, M., Barwinski, R., \& Kraus, S. (2020). Coworking spaces: Empowerment for entrepreneurship and innovation in the digital and sharing economy. Journal of Business Research, 114, 102-110.

7. Efendi, S. (2020). The Role of Human Capital in the Education Sector in Efforts to Create Reliable Organizational Human Resources. International Journal of Science and Society, 2(1), 405-413.

8. Efendi, S. (2021). Lecturer's Pedagogic Competence in Developing Student Learning at the National University. Jurnal Mantik, 5(2), 701-706.

9. Efendi, S. (2021). The Role of Knowledge-Based Signature Skill (Specific Knowledge-Based Professional Ability) as a Mediation Variable in Intellectual Capital, Intrinsic Motivation, Empowerment of Creativity on Performance: (Empirical Study at Private Universities DKI Jakarta). Italienisch, 11(2), 321-334.

10. Efendi, S. (2021, June). Implementation of Talent Management as an Effort to Improve Employee Performance. In 2nd Annual Conference on blended learning, educational technology and Innovation (ACBLETI 2020) (pp. 537-542). Atlantis Press.

11. Efendi, S., \& Winenriandhika, O. (2021). Pengaruh Rekrutmen, Pelatihan Dan Pengalaman Kerja Terhadap Kepuasan Kerja Dan Dampaknya Pada Kinerja Karyawan Di Pt. Marketama Indah. Akselerasi: Jurnal Ilmiah Nasional, 3(1), 99-110.

12. Efendi, S., \& Winenriandhika, O. (2021). Pengaruh Rekrutmen, Pelatihan Dan Pengalaman Kerja Terhadap Kepuasan Kerja Dan Dampaknya Pada Kinerja Karyawan Di Pt. Marketama Indah. Akselerasi: Jurnal Ilmiah Nasional, 3(1), 99-110.

13. Hameed, W. U., Nisar, Q. A., \& Wu, H. C. (2021). Relationships between external knowledge, internal innovation, firms' open innovation performance, service innovation and business performance in the Pakistani hotel industry. International Journal of Hospitality Management, 92, 102745.

14. Kumar, S., Singh, V., \& Haleem, A. (2014). Knowledge management-enablers and barriers: a questionnaire-based study. International Journal of Knowledge Engineering and Data Mining, 3(1), 31-57.

15. Kusumawati, R. (2010). Pengaruh karakteristik pimpinan dan inovasi produk baru terhadap kinerja perusahaan untuk mencapai keunggulan bersaing berkelanjutan. AKSES: Jurnal Ekonomi dan Bisnis, 5(9).

16. Latief, A., Nurlina, N., Medagri, E., \& Suharyanto, A. (2019). Pengaruh Manajemen Pengetahuan, Keterampilan dan Sikap terhadap Kinerja Karyawan. JUPIIS: Jurnal Pendidikan Ilmu-Ilmu Sosial, 11(2), 173-182.

17. Latief, A., Nurlina, N., Medagri, E., \& Suharyanto, A. (2019). Pengaruh Manajemen Pengetahuan, Keterampilan dan Sikap terhadap Kinerja Karyawan. JUPIIS: Jurnal Pendidikan Ilmu-Ilmu Sosial, 11(2), 173-182.

18. Mahmood, T., \& Mubarik, M. S. (2020). Balancing innovation and exploitation in the fourth industrial revolution: Role of intellectual capital and technology absorptive capacity. Technological Forecasting and Social Change, 160, 120248. 
19. Mubarik, M. S., Bontis, N., Mubarik, M., \& Mahmood, T. (2021). Intellectual capital and supply chain resilience. Journal of Intellectual Capital.

20. Nisa, R. C., Astuti, E. S., \& Prasetya, A. (2016). Pengaruh Manajemen Talenta Dan Manajemen Pengetahuan Terhadap Kinerja Karyawan (Studi pada Karyawan PT. PLN (Persero) Distribusi Jawa Timur, Surabaya). Jurnal Administrasi Bisnis, 39(2), 141-148.

21. Schilling, M. A., \& Hill, C. W. (1998). Managing the new product development process: strategic imperatives. Academy of Management Perspectives, 12(3), 67-81.

22. Sugiono, E. (2021). The Influence of Transformational Leadership, Talent Management, and Employee Placement on Employee Engagement and Its Implications for Employee Performance: Case Study of Premier Bintaro Hospital, South Tangerang City, Indonesia. Dialogos, 25(1), 32-42.

23. Sugiono, E., \& Efendi, S. (2020). Leadership Style, Work Discipline, and Compensation to Employee Performance through Job Satisfaction. Endless: International Journal of Future Studies, 3(2), 47-63.

24. Sugiono, E., Efendi, S., \& Al-Afgani, J. (2021). Pengaruh Motivasi Kerja, Kompetensi, Dan Kompensasi Terhadap Kinerja Karyawan Melalui Kepuasaan Kerja Pt. Wibee Indoedu Nusantara (Pustaka Lebah) Di Jakarta. Jurnal Ilmiah MEA (Manajemen, Ekonomi, \& Akuntansi), 5(1), 718-734.

25. Sugiono, E., Effendi, S., \& Alwan, B. (2021). Pengaruh Komitmen Organisasi, Motivasi, Disiplin, Terhadap Kepuasan Kerja Dalam Pelaksanaan Perjanjian Kerja Bersama (PKB) Dan Dampaknya Terhadap Kinerja Karyawan Pada Pt. Pakoakuina. Jurnal Ilmiah MEA (Manajemen, Ekonomi, \& Akuntansi), 5(1), 783-802.

26. Sugiono, E., Effendi, S., \& Alwan, B. (2021). Pengaruh Komitmen Organisasi, Motivasi, Disiplin, Terhadap Kepuasan Kerja Dalam Pelaksanaan Perjanjian Kerja Bersama (Pkb) Dan Dampaknya Terhadap Kinerja Karyawan Pada PT. Pakoakuina. Jurnal Ilmiah MEA (Manajemen, Ekonomi, \& Akuntansi), 5(1), 783-802.

27. Sugiono, E., Hidayat, D. O., \& Efendi, S. (2020). Pengaruh Iklim Organisasi, Pelatihan Dan Kompensasi Terhadap Kepuasan Kerja Dan Dampaknya Terhadap Kinerja Pegawai Yayasan Mantab AL Hamid. Jurnal Ilmiah MEA (Manajemen, Ekonomi, E Akuntansi), 4(2), 602-627.

28. Sumardi, R., \& Efendi, S. (2021). Upaya Meningkatkan Kinerja Dengan Pendekatan Aplikasi Balance Scorecard Pada Perguruan Tinggi Swasta Di Jakarta. Jurnal Sosial dan Humaniora, 4(8), 229-242. 